\title{
Synthesis, characterization and catalytic application of Ni catalysts supported on alumina-zirconia mixed oxides
}

\author{
J ÁNGEL-SOTO',*®, M MARTÍNEZ-ROSALES ${ }^{2}$, P ÁNGEL-SOTO $^{3}$ and \\ A ZAMORATEGUI-MOLINA ${ }^{4}$ \\ ${ }^{1}$ Department of Chemical Engineering, University of Guanajuato, Noria Alta S/N, 36050 Guanajuato, Mexico \\ ${ }^{2}$ Department of Chemistry, University of Guanajuato, Noria Alta S/N, 36050 Guanajuato, Mexico \\ ${ }^{3}$ Department of Industrial Engineering, Technological Institute of Leon, Industrial Julian de Obregon, 37290 León, Mexico \\ ${ }^{4}$ Department of Civil Engineering, University of Guanajuato, Avenida Juárez No. 77, Zona Centro, 36000 Guanajuato, \\ Mexico \\ *Author for correspondence (jasoto@ugto.mx)
}

MS received 31 October 2016; accepted 20 March 2017; published online 11 November 2017

\begin{abstract}
Alumina and alumina-zirconia mixed oxides were compared as supports to prepare nickel catalysts. The oxides were prepared by the sol-gel method using aluminum tri-sec-butoxide and zirconium (IV) propoxide as precursors, and its physicochemical properties were determined by BET, TGA, DTA, XRD, SEM and TEM. The catalysts of nickel were obtained by the impregnation of the supports with nickel nitrate $(10 \mathrm{wt} \%)$ and were heat-treated at $700^{\circ} \mathrm{C}$. The specific area of the supports and catalysts decreased with the increase in the zirconia content in agreement with the crystalline phase formed. TEM micrographs of nickel catalysts revealed particles in the size range of $10-30 \mathrm{~nm}$. The Ni/Al $\mathrm{O}_{3}-\mathrm{ZrO}_{2}$ catalysts were tested in the steam reforming reaction of ethanol $(\mathrm{SRE})$ at $500^{\circ} \mathrm{C}$, and the obtained results suggest that the differences in catalytic activities depended on the content of $\mathrm{ZrO}_{2}$. The selectivity towards $\mathrm{H}_{2}$ was $\sim 56 \%$ for the named catalyst $\mathrm{Ni}-\mathrm{Al}-0.25 \mathrm{Zr}$.
\end{abstract}

Keywords. Alumina; alumina-zirconia mixed oxides; sol-gel method; nickel catalysts; steam reforming.

\section{Introduction}

The catalysts $\gamma-\mathrm{Al}_{2} \mathrm{O}_{3}$ is widely used because it can provide high surface area for many applications $[1,2]$. One of the most important factors in $\gamma-\mathrm{Al}_{2} \mathrm{O}_{3}$ utilization is a controlled poresize distribution and its thermal stability [3].

Zirconia is a essential material with growing application in heterogeneous catalysis, both as an active material or as a support. It is also a relevant material in adsorption [4]. Fine particles of zirconia show a better wear resistance and lower resistance to diffusion, while nanocrystalline zirconia has a high adsorptive capacity, which is favourable for catalysis and adsorption applications, respectively [5].

The oxide of zirconium is characterized by high chemical resistance and is stable over a wide temperature range. Furthermore, it possesses both acidic and basic centres. Therefore, it can act as a basic or an acid catalyst, and hence, additional attempts are made to improve the properties of zirconia and alumina supports forming mixed oxides of $\mathrm{Al}-$ $\mathrm{Zr}$ [6]. The alumina mixed oxides present higher catalytic behaviour than the pure $\mathrm{ZrO}_{2}$ or $\mathrm{Al}_{2} \mathrm{O}_{3}$, because they present more thermal stability, medium acidity and moderate surface area [7-9].
Several methods are used to synthesize the catalyst supports, such as coprecipitation, plasma, homogeneous precipitation and sol-gel methods, which are all reported in the literature. In this regard, the sol-gel method can control the pore size, surface area and high purity materials better than other preparation methods, such as the coprecipitation method.

In recent years, the Ni-based catalysts on alumina-zirconia have attracted much interest owing to the fact that nickel has a low cost and can break $\mathrm{C}-\mathrm{C}$ bonds in reforming reactions of hydrocarbons [10-12]. In this type of reaction, the catalysts based on noble metals such as $\mathrm{Pd}, \mathrm{Rh}, \mathrm{Pt}$, etc. are less sensitive to coke formation, compared to nickel-based catalysts. However, the catalysts have the disadvantage of high cost and limited availability, which is important in the development of active and stable nickel catalysts to different research groups [13-15].

The aim of the present work is to prepare and characterize $\mathrm{Ni}$ catalysts supported over $\mathrm{Al}_{2} \mathrm{O}_{3}-\mathrm{ZrO}_{2}$ mixed oxides, also to study the effect of zirconia content in the obtained catalysts, performing reactions with them in the steam reforming case at $500^{\circ} \mathrm{C}$. In this study, the alumina-zirconia supports were synthesized by the sol-gel method using three different molar ratio samples of $\mathrm{Al}_{2} \mathrm{O}_{3} / \mathrm{ZrO}_{2}$. 


\section{Methods and procedures}

\subsection{Synthesis of $\mathrm{Al}_{2} \mathrm{O}_{3}-\mathrm{ZrO}_{2}$ mixed oxides and $\mathrm{Ni}$-based catalyst}

The $\mathrm{Al}_{2} \mathrm{O}_{3}-\mathrm{ZrO}_{2}$ mixed oxides synthesized by the sol-gel method used the following procedure with a molar ratio of 80/30/0.3/1 (alcohol/water/acid/alkoxide). Appropriate quantities of aluminum tri-sec-butoxide (97\%, Aldrich) and anhydrous ethanol $(94.2 \%, \mathrm{~J}$ T Baker) were mixed in a reactor vessel with continuous stirring for 20 min under an inert atmosphere of nitrogen. In another vessel-reactor, zirconium (IV) propoxide (70 wt\%, Aldrich) and the appropriate amount of ethanol were mixed under an inert atmosphere of nitrogen, stirred briskly for $20 \mathrm{~min}$. Then, both solutions were blended by stirring the mixture vigorously for $2 \mathrm{~h}$ at room temperature until a clear solution was obtained. To this solution, an aqueous solution of $\mathrm{HNO}_{3}(65 \%$, J T Baker) was added dropwise at room temperature. The gel formed was aged for $24 \mathrm{~h}$ at room temperature. The starting heat treatment step is to dry the powder up to $120^{\circ} \mathrm{C}$ for $1 \mathrm{~h}$ at a heating rate of $1^{\circ} \mathrm{C} \mathrm{min}{ }^{-1}$ starting at room temperature. The resulting powder was finally heattreated up to $700^{\circ} \mathrm{C}$ for $2 \mathrm{~h}$ at a heating rate of $0.5^{\circ} \mathrm{C} \mathrm{min}^{-1}$. Three samples of $\mathrm{Al}_{2} \mathrm{O}_{3}-\mathrm{ZrO}_{2}$ mixed oxides were prepared with different molar ratios of $\mathrm{Al}_{2} \mathrm{O}_{3} / \mathrm{ZrO}_{2}, X=0.25: 1,1: 1$, $1: 0.25$, which are further denoted as $0.25 \mathrm{Al}-\mathrm{Zr}, \mathrm{Al}-\mathrm{Zr}$ and $\mathrm{Al}-0.25 \mathrm{Zr}$. $\mathrm{Al}_{2} \mathrm{O}_{3}$ support was obtained using the procedure described above.

The supported nickel catalysts were prepared by impregnating the $\mathrm{Al}_{2} \mathrm{O}_{3}-\mathrm{ZrO}_{2}$ and $\mathrm{Al}_{2} \mathrm{O}_{3}$ support with an aqueous solution of $\mathrm{Ni}\left(\mathrm{NO}_{3}\right)_{2} \cdot 6 \mathrm{H}_{2} \mathrm{O}(\mathrm{J}$ T Baker) using a nickel load of $10 \mathrm{wt} \%$ for all the samples. The fresh catalysts were dried at room temperature for $24 \mathrm{~h}$ and were then calcined using the same temperature ramp which is utilized previously for the supports. The catalysts are denoted as $\mathrm{Ni}-0.25 \mathrm{Al}-\mathrm{Zr}, \mathrm{Ni}-$ $\mathrm{Al}-\mathrm{Zr}, \mathrm{Ni}-\mathrm{Al}-0.25 \mathrm{Zr}$ and $\mathrm{Ni}-\mathrm{Al}_{2} \mathrm{O}_{3}$.

\subsection{Characterization of supports and catalysts}

Textural characterization of the supports and catalysts samples were made by $\mathrm{N}_{2}$ adsorption-desorption using a Micromeritics ASAP 2010 instrument. The pore-size distributions were determined by the Barret-Joyner-Hallenda (BJH) method, applied to the desorption branch-profile of the nitrogen isotherm. The crystal structure of the different supports and catalysts was determined by an Inel EQUINOX 3000D diffractometer using monochromatic $\mathrm{CuK} \alpha$ radiation, scanning $2 \theta$ from 10 to $80^{\circ}$. Thermal analysis of the $\mathrm{Al}_{2} \mathrm{O}_{3}$ and $\mathrm{Al}_{2} \mathrm{O}_{3}-\mathrm{ZrO}_{2}$ mixed oxides was carried out using an SDT Q600 simultaneous TGA-DSC instrument. Measurements were performed at a heating rate of $10^{\circ} \mathrm{C} \mathrm{min}^{-1}$ up to $1000^{\circ} \mathrm{C}$ in air at $100 \mathrm{ml} \mathrm{min}^{-1}$. Microstructural characterization of the supports was made in a scanning electron microscope (SEM, JEOL JSM-6400) with an acceleration voltage of $20 \mathrm{kV}$. The microstructure of catalysts was studied by transmission electron microscope (TEM) images obtained on a Philips Tecnai
F20 (field emission scanning electron microscope (FESEM)) instrument operated at an accelerating voltage of $200 \mathrm{kV}$.

The coke deposited on the used catalysts was detected by DTA analysis, which was carried out with a Netzsch, STA-409EP thermal analyzer. It was performed from room temperature to $1000^{\circ} \mathrm{C}$ at a heating rate of $10^{\circ} \mathrm{C} \mathrm{min}{ }^{-1}$ in static air.

\subsection{Catalytic evaluation of $\mathrm{Ni} / \mathrm{Al}-\mathrm{Zr}$ catalysts}

The steam reforming reaction of ethanol (SRE) reaction was conducted in a fixed-bed quartz reactor with an inner diameter of $10 \mathrm{~mm}$ using $50 \mathrm{mg}$ of catalyst. The catalysts were activated in situ by a reduction step at atmospheric pressure under $\mathrm{H}_{2}$ flow $\left(40 \mathrm{ml} \mathrm{min}^{-1}\right)$ at $650^{\circ} \mathrm{C}$ for $2 \mathrm{~h}$. Steam reforming measurements were conducted at $500^{\circ} \mathrm{C}$ and at atmospheric pressure. The product mixture was analysed by an on-line gas chromatograph (GC), equipped with a flame ionization detector (FID) and a thermal conductivity detector (TCD).

\section{Results and discussion}

\subsection{Textural properties}

The nitrogen adsorption-desorption isotherms for $\mathrm{Al}_{2} \mathrm{O}_{3}$, $\mathrm{Al}_{2} \mathrm{O}_{3}-\mathrm{ZrO}_{2}$ mixed oxides and $\mathrm{Ni}$ catalysts heat-treated at $700^{\circ} \mathrm{C}$ are shown in figure 1 . In this figure, all isotherms of the supports and Ni catalysts are type IV, profiles characteristic of mesoporous materials. The hysteresis loops in these curves are E-type according to IUPAC, these indicate the existence of tubular pores with narrow openings, or inkwell type pores.

The pore-size distribution of the supports and $\mathrm{Ni}$ catalysts are shown in figure 2. The results indicate that only a unimodal pore-size distribution is obtained in the supports and catalysts [16]. Actually, the incorporation of small amounts of zirconia to alumina does not affect the average pore-size distribution; with the increasing zirconia content in the mixed oxides, the average pore-size distribution becomes smaller [17], as seen in figure $2 \mathrm{a}$. The average diameter poresize distribution of the supports varies from $54 \AA$ toofpure alumina to $45 \AA$ for the mixed oxide, which is richer in zirconium content $(0.25 \mathrm{Al}-\mathrm{Zr})$.

The average pore-size distribution for the Ni-catalysts shows the same effect as the supports as seen in figure $2 b$, in which the average pore diameter ranges from $50 \AA$ for the $\mathrm{Ni}-\mathrm{Al}-\mathrm{Zr}$ catalyst to $42 \AA$ for the $\mathrm{Ni}-0.25 \mathrm{Al}-\mathrm{Zr}$ catalyst. When comparing the distribution of the pore-size for the supports and catalysts, it may be seen that those are very similar, which in turn suggests that the dispersion of nickel metal load on the supports was homogeneous.

The specific surface areas of the supports and catalysts heattreated at $700^{\circ} \mathrm{C}$, as well as average pore diameter and pore volume are summarized in table 1 . The surface area of the 

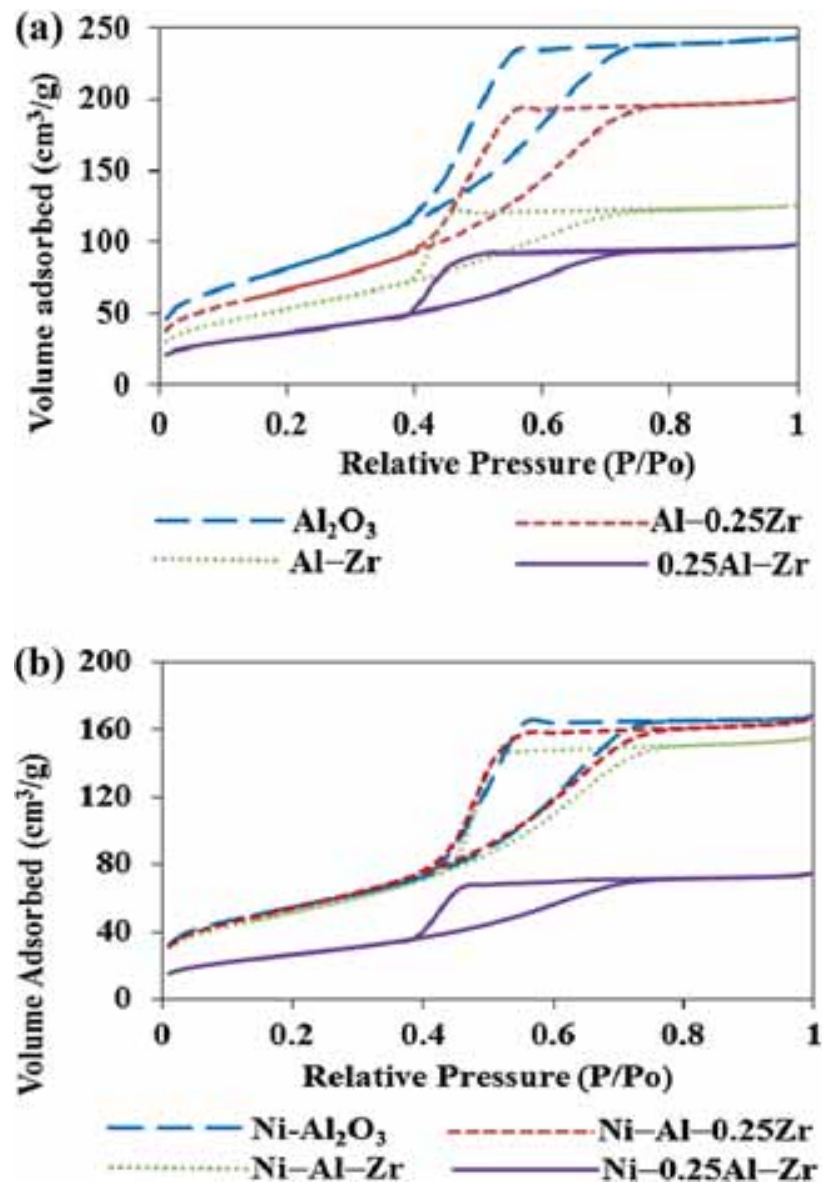

Figure 1. $\mathrm{N}_{2}$ adsorption-desorption isotherms: (a) supports and (b) Ni-catalysts, heat-treated at $700^{\circ} \mathrm{C}$.

supports (from 295 to $132 \mathrm{~m}^{2} \mathrm{~g}^{-1}$ ) and catalysts (from 210 to $95 \mathrm{~m}^{2} \mathrm{~g}^{-1}$ ) are decreased with the increment in the content of zirconium $[18,19]$; this is due to a diminution in the $\gamma-\mathrm{Al}_{2} \mathrm{O}_{3}$ content with high surface area, caused by the addition of $\mathrm{ZrO}_{2}$ to the $\mathrm{Al}_{2} \mathrm{O}_{3}$. The same trend is present in the pore volume and average pore diameters in the supports and Ni-catalysts.

\subsection{XRD analysis}

The X-ray diffraction pattern (XRD) of the $\mathrm{Al}_{2} \mathrm{O}_{3}$ and $\mathrm{Al}-$ $\mathrm{Zr}$ mixed oxides heat-treated at $700^{\circ} \mathrm{C}$ are presented in figure 3. In the $\mathrm{Al}_{2} \mathrm{O}_{3}$ support, two small lumps at $2 \theta$ $46^{\circ}$ and $2 \theta-66^{\circ}$ corresponded to diffractions of $\gamma-\mathrm{Al}_{2} \mathrm{O}_{3}$ as shown in figure $3 \mathrm{a}$. However, no intense peaks are observed because the synthesized alumina has an incipient ordered structure.

The three $\mathrm{Al}-\mathrm{Zr}$ mixed oxides are synthesized as shown in figure $3 b-d$, there was no clear characteristic peak corresponding to the spectrum of the $\mathrm{Al}_{2} \mathrm{O}_{3}$ support, indicating that $\mathrm{ZrO}_{2}$ was highly dispersed into alumina, thereby forming a solid solution. A moderate plateau of tetragonal $\mathrm{ZrO}_{2}$ is shown at $2 \theta-30^{\circ}$ in the mixed oxides, which increased with
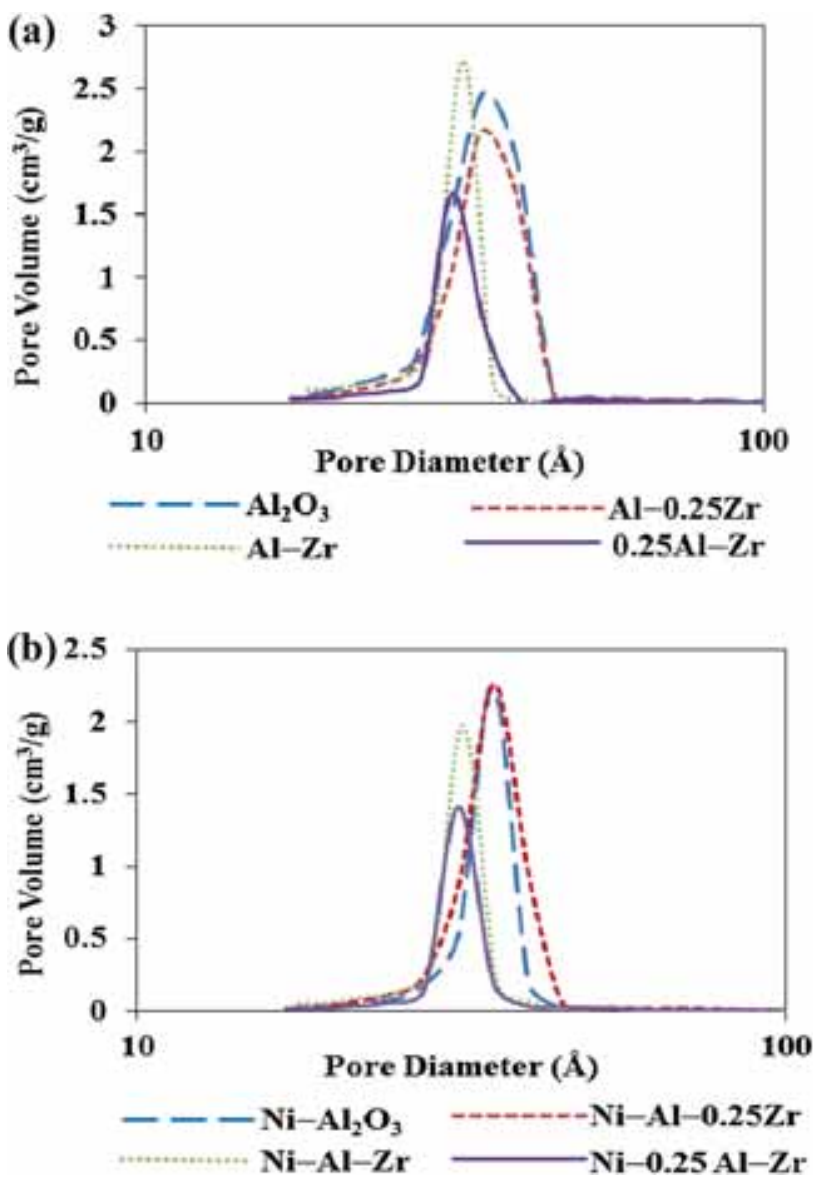

Figure 2. Pore-size distribution: (a) supports and (b) Ni-catalysts, heat-treated at $700^{\circ} \mathrm{C}$.

Table 1. Textural properties of $\mathrm{Al}_{2} \mathrm{O}_{3}-\mathrm{ZrO}_{2}$ supports and $\mathrm{Ni}$ catalysts heat-treated at $700^{\circ} \mathrm{C}$.

\begin{tabular}{lccc}
\hline Sample & $S_{\text {BET }}\left(\mathrm{m}^{2} \mathrm{~g}^{-1}\right)$ & $D_{\mathrm{p}}(\AA)$ & $V_{\mathrm{p}}\left(\mathrm{cm}^{3} \mathrm{~g}^{-1}\right)$ \\
\hline $\mathrm{Al}_{2} \mathrm{O}_{3}$ & 295 & 53 & 0.5 \\
$\mathrm{Al}-0.25 \mathrm{Zr}$ & 240 & 51.5 & 0.46 \\
$\mathrm{Al}-\mathrm{Zr}$ & 190 & 50 & 0.41 \\
$0.25 \mathrm{Al}-\mathrm{Zr}$ & 130 & 44.6 & 0.35 \\
$\mathrm{Ni}-\mathrm{Al}{ }_{2} \mathrm{O}_{3}$ & 210 & 50 & 0.41 \\
$\mathrm{Ni}-\mathrm{Al}-0.25 \mathrm{Zr}$ & 195 & 51 & 0.41 \\
$\mathrm{NiAl}-\mathrm{Zr}$ & 140 & 46 & 0.33 \\
$\mathrm{Ni}-0.25 \mathrm{Al}-\mathrm{Zr}$ & 95 & 42.3 & 0.18 \\
\hline
\end{tabular}

increasing zirconia content. However, the plateau was also considered as the appearance of amorphous zirconia [19, 20]. Therefore, the mixed oxides are amorphous with the $0.25 \mathrm{Al}-\mathrm{Zr}$ oxide presenting an incipient crystallinity as observed in figure $3 \mathrm{~d}$.

Figure 4 shows the XRD spectra of catalysts with $10 \mathrm{wt} \%$ heat-treated at $700^{\circ} \mathrm{C}$. Four peaks at $2 \theta: 37.2,44,63$ and $75.5^{\circ}$ are attributed to the (111), (200), (220) and (311) planes of 


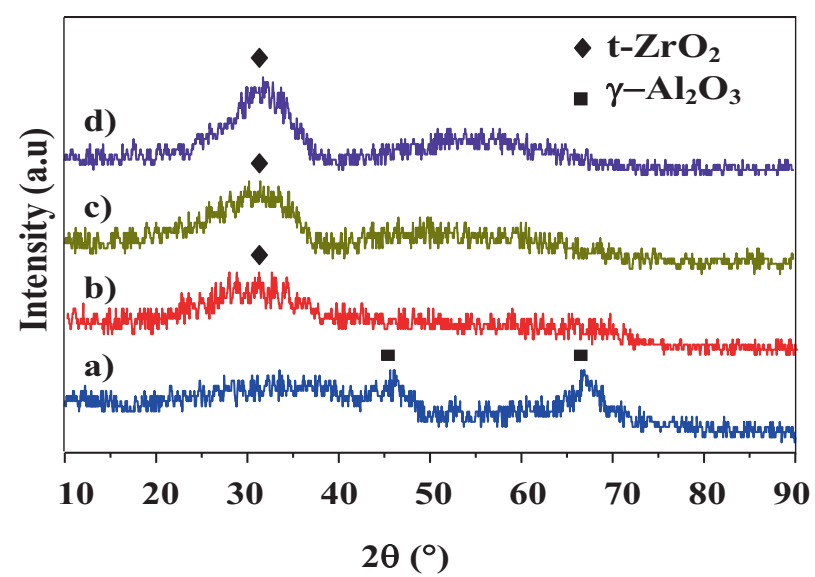

Figure 3. XRD patterns of supports heat-treated at $700^{\circ} \mathrm{C}$ : (a) $\gamma-\mathrm{Al}_{2} \mathrm{O}_{3}$, (b) $\mathrm{Al}-0.25 \mathrm{Zr}$, (c) $\mathrm{Al}-\mathrm{Zr}$ and (d) $0.25 \mathrm{Al}-\mathrm{Zr}$.

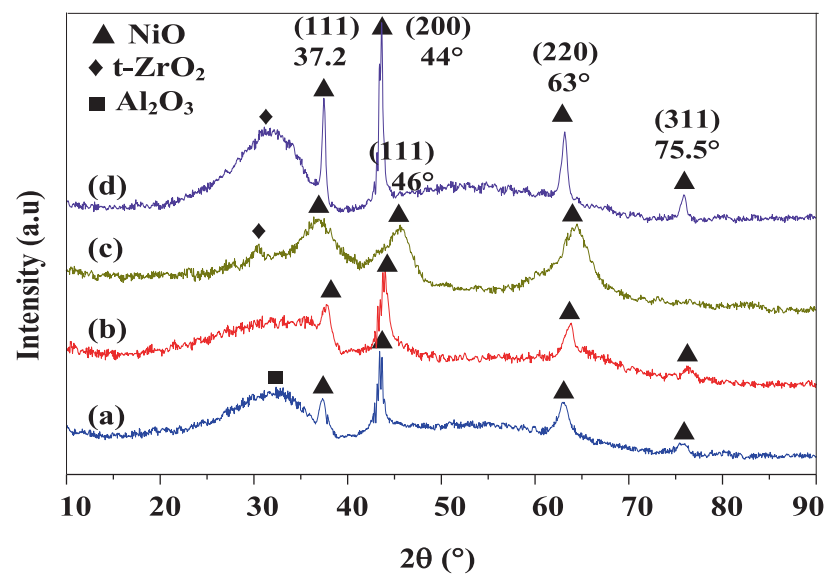

Figure 4. XRD patterns of Ni-catalysts: (a) $\mathrm{Ni}-\mathrm{Al}_{2} \mathrm{O}_{3},(\mathbf{b}) \mathrm{Ni}-\mathrm{Al}-$ $0.25 \mathrm{Zr}$, (c) $\mathrm{Ni}-\mathrm{Al}-\mathrm{Zr}$ and (d) $\mathrm{Ni}-0.25 \mathrm{Al}-\mathrm{Zr}$.

$\mathrm{NiO}$ in the crystalline phase, respectively, and are observed on the $\mathrm{Ni}$ catalysts [21]. The $\mathrm{Ni}-\mathrm{Al}_{2} \mathrm{O}_{3}$ catalyst also shows a small shoulder at $2 \theta \approx 32^{\circ}$ that may result from the gamma phase alumina, due to the second heat treatment. This shoulder may also be due to the interaction of $\mathrm{Ni}$ with alumina to form the crystalline phase $\mathrm{NiAl}_{2} \mathrm{O}_{4}$, which has a stable and desirable structure, and is difficult to reduce [22].

The Ni- $0.25 \mathrm{Zr}-\mathrm{Al}_{2} \mathrm{O}_{3}$ catalyst does not present a clear diffraction peak for $\mathrm{ZrO}_{2}$, indicating that the $\mathrm{ZrO}_{2}$ was highly dispersed into alumina. However, the peak at $2 \theta$ of $30.5^{\circ}$ of tetragonal $\mathrm{ZrO}_{2}$ present in the $\mathrm{Al}-\mathrm{Zr}$ and $0.25 \mathrm{Al}-\mathrm{Zr}$ supports appears at $2 \theta$ of 31.5 and $32^{\circ}$ in the XRD spectra of the Ni-Al$\mathrm{Zr}$ and $\mathrm{Ni}-0.25 \mathrm{Al}-\mathrm{Zr}$ catalysts, respectively. This is because of the lattice of $\mathrm{ZrO}_{2}$ is contracted by the incorporation of $\mathrm{Al}^{+3}$ ions into $\mathrm{ZrO}_{2}$ [23]. The diffraction intensities of the $\mathrm{NiO}$ crystals have become stronger by increasing the content of zirconium in mixed oxides of $\mathrm{Al}_{2} \mathrm{O}_{3}-\mathrm{ZrO}_{2}$, indicating that $\mathrm{Ni}^{+2}$ ions interact more strongly with the alumina as zirconia content is increased.

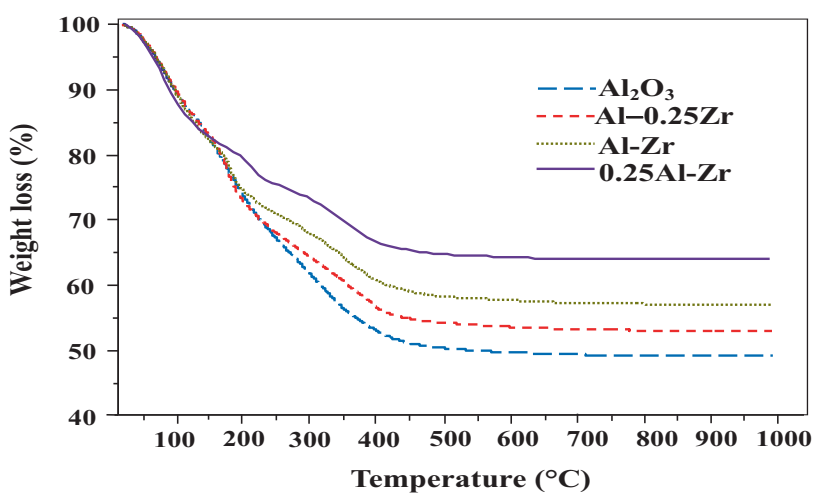

Figure 5. TGA curves of the $\mathrm{Al}_{2} \mathrm{O}_{3}-\mathrm{ZrO}_{2}$ supports.

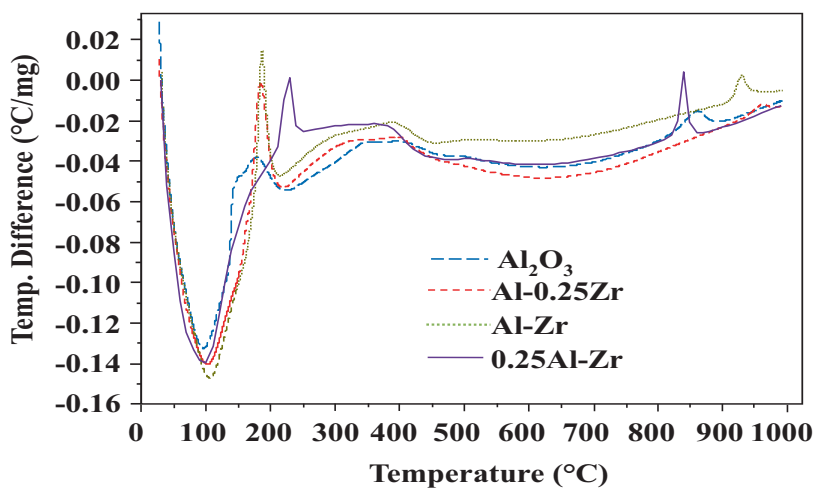

Figure 6. DTA of $\mathrm{Al}_{2} \mathrm{O}_{3}-\mathrm{ZrO}_{2}$ supports.

\subsection{Thermal analysis}

Thermal analyses of the fresh supports are illustrated in figure 5. In the thermogravimetric analysis (TGA) curve for the pure alumina, the weight loss percentage from room temperature to $150^{\circ} \mathrm{C}$ was measured about $15.1 \%$, which is consistent with a broad endothermic peak in the DTA curve, as seen in figure 6 . This result is attributed to the elimination of residual water and physically adsorbed ethanol. A second weight loss, about $19.7 \%$, was measured at $150-262^{\circ} \mathrm{C}$ in the TGA curve, which is represented by an exothermic peak in the DTA curve and can be attributed to the incipient combustion of residual organic compounds (alkoxides) synthesis. The third weight loss $(9.7 \%)$ from 262 to $379^{\circ} \mathrm{C}$ is associated with an exothermic peak in the DTA curve, and is related to dehydroxylation of the boehmite to the $\gamma-\mathrm{Al}_{2} \mathrm{O}_{3}$ phase $[17,24]$.

Between 379 and $440^{\circ} \mathrm{C}$, a fourth weight loss (3.1\%) occurs in the TGA curve, which is associated with the combustion of occluded organic molecules [25,26], and is represented by a small exothermic peak in the DTA curve. In the temperature range of $440-510^{\circ} \mathrm{C}$, a fifth weight loss of about $1.2 \%$ occurs, which is represented by a change in the exothermic DTA curve, and is associated with the final formation of $\gamma-\mathrm{Al}_{2} \mathrm{O}_{3}$ [27], as seen in the XRD analyses. The TGA curve 
shows a small weight loss $(\sim 0.3 \%)$ between 800 and $900^{\circ} \mathrm{C}$ related with a small exothermic peak, and should be attributed to the crystallization of alumina.

The fresh $\mathrm{Al}_{2} \mathrm{O}_{3}-\mathrm{ZrO}_{2}$ mixed oxides show five weight losses in the TGA curve. In the range of $27-120^{\circ} \mathrm{C}$, the weight loss of $16,18.2$ and $19.1 \%$ in the $\mathrm{Al}-0.25 \mathrm{Zr}, \mathrm{Al}-\mathrm{Zr}$ and $0.25 \mathrm{Al}-\mathrm{Zr}$ supports, respectively, correspond to the first broad endothermic peak in the DTA curve, and is ascribed to the evaporation of ethanol and adsorbed water from the $\mathrm{Al}_{2} \mathrm{O}_{3}-\mathrm{ZrO}_{2}$ mixed oxides. Between 170 and $240^{\circ} \mathrm{C}$, a second weight loss occurs $(3.1 \%)$ in the TGA curve for $\mathrm{Al}_{2} \mathrm{O}_{3}-\mathrm{ZrO}_{2}$ mixed oxides with weight loss about 17.8, 11.8 and 5.8\%. In the aforementioned order of the mixed oxides, which is mainly associated with the initial combustion of alkoxides (aluminum tri-sec-butoxide and zirconium (IV) propoxide), and is represented by a change in the exothermic DTA curve. In the $0.25 \mathrm{Al}-\mathrm{Zr}$ support, this exothermic peak (centred at around $210^{\circ} \mathrm{C}$ ) is observed and is shifted to the right in the DTA curves, indicating that initial combustion is mainly due to the burning of aluminum tri-sec-butoxide. The third weight loss ( $\sim 6.2$ and $\sim 6.8 \%$ ) was measured from 240 to $360^{\circ} \mathrm{C}$ in the $\mathrm{Al}-0.25 \mathrm{Zr}$ and $\mathrm{Al}-\mathrm{Zr}$ supports, respectively, is related to a small exothermic peak in the DTA curve, and is associated with the elimination of chemically bonded water [17].
Another small exothermic peak is observed in the DTA curve at about $400^{\circ} \mathrm{C}$ for $\mathrm{Al}-0.25 \mathrm{Zr}$ and $\mathrm{Al}-\mathrm{Zr}$ supports, which can be attributed to the tetragonal phase of $\mathrm{ZrO}_{2}$. This result represents the fourth weight loss of about 5.7 and $5.3 \%$ in the TGA curve for the $\mathrm{Al}-0.25 \mathrm{Zr}$ and $\mathrm{Al}-\mathrm{Zr}$ supports, which was observed in XRD results.

On the other hand, the TGA curve of $0.25 \mathrm{Al}-\mathrm{Zr}$ support the third and fourth weight losses $(\sim 8.5 \%)$ that are observed only at a temperature range of $210-410^{\circ} \mathrm{C}$. Finally, a weight loss for all mixed oxides occurs between 800 and $1000^{\circ} \mathrm{C}$, represented by a small exothermic peak in the DTA curve, corresponding to the transformation of the tetragonal into the monoclinic zirconia phase $[19,28]$.

\subsection{SEM analysis}

The microstructures of the supports of $\mathrm{Al}_{2} \mathrm{O}_{3}-\mathrm{ZrO}_{2}$ were analysed by SEM as shown in figure 7. The images show that the supports are formed from mesoporous agglomerates of homogeneous-sized particles with a spherical shape, and with a rough size of $0.3 \mu \mathrm{m}$ on the scale of resolution, indicating that the supports are amorphous, as evidenced by the XRD studies. It is evident that the particle size increases with
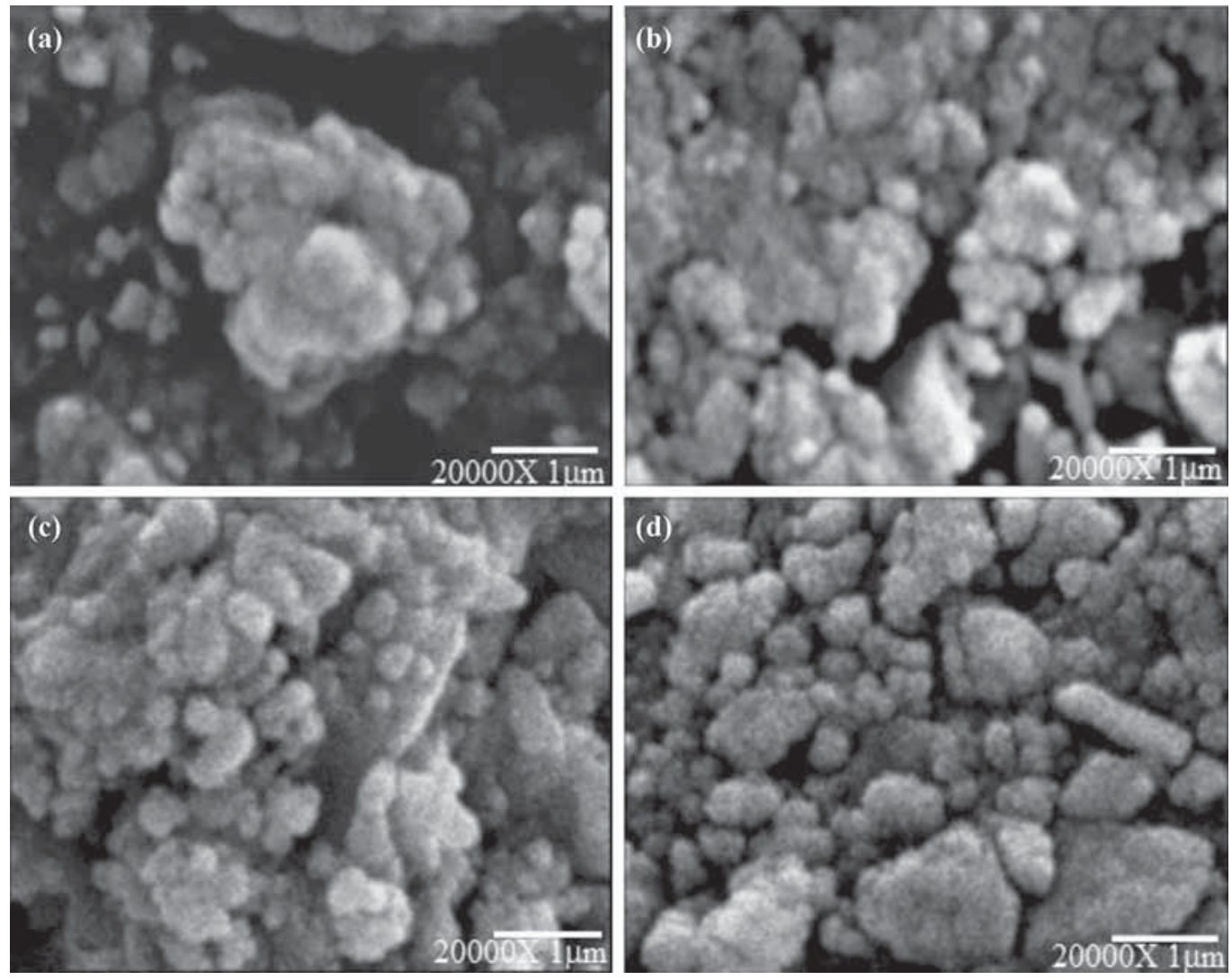

Figure 7. Micrograph by SEM of: (a) $\mathrm{Al}_{2} \mathrm{O}_{3}$, (b) $\mathrm{Al}-0.25 \mathrm{Zr}$, (c) $\mathrm{Al}-\mathrm{Zr}$ and (d) $0.25 \mathrm{Al}-\mathrm{Zr}$ supports heattreated at $700^{\circ} \mathrm{C}$. 

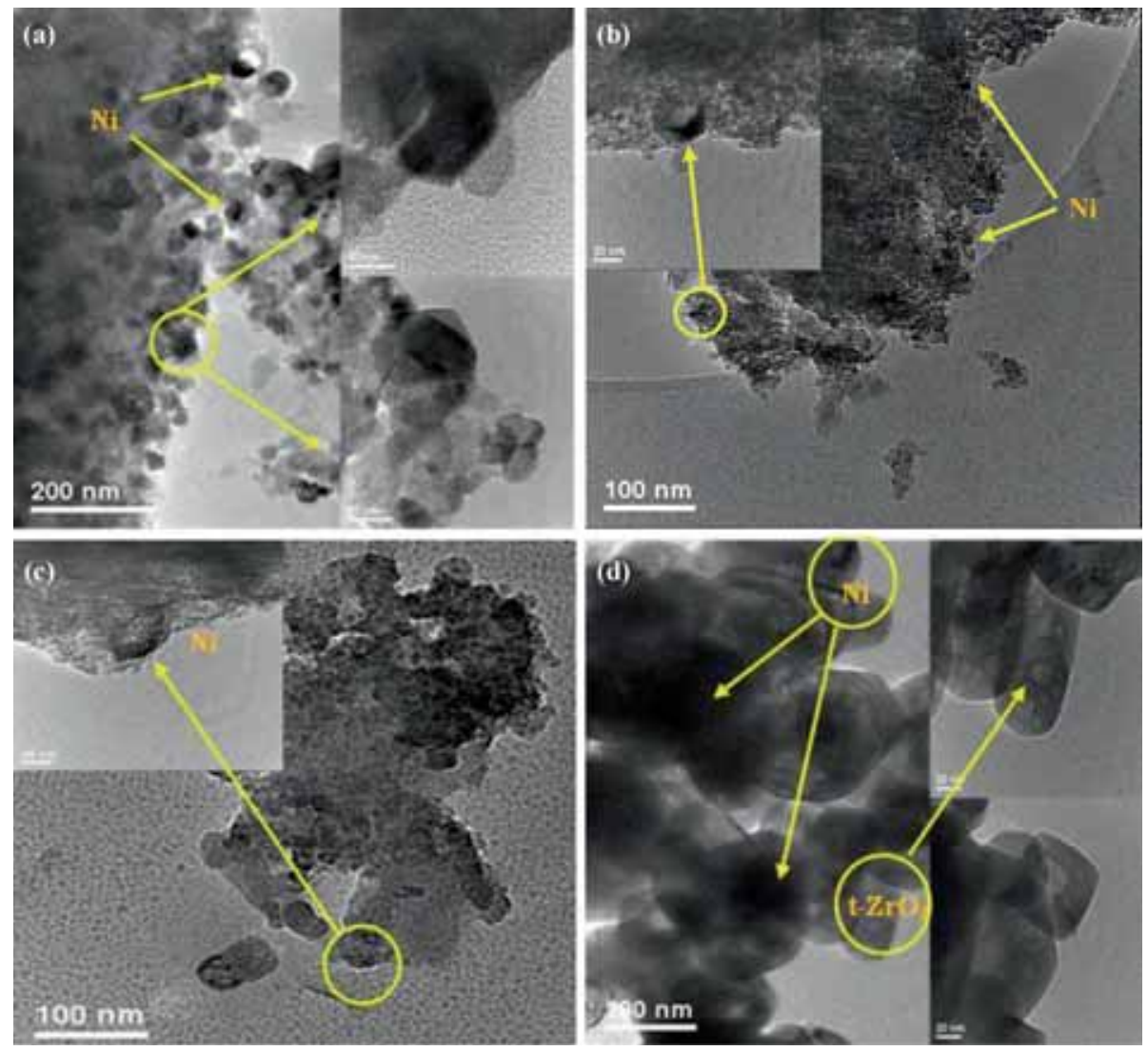

Figure 8. TEM micrographs of: (a) $\mathrm{Ni}-\mathrm{Al}_{2} \mathrm{O}_{3}$, (b) $\mathrm{Ni}-\mathrm{Al}-0.25 \mathrm{Zr}$, (c) $\mathrm{Ni}-\mathrm{Al}-\mathrm{Zr}$, (d) $\mathrm{Ni}-$ $0.25 \mathrm{Al}-\mathrm{Zr}$ heat-treated at $700^{\circ} \mathrm{C}$.

increasing zirconia content, whereby the size of the agglomerates decreases; this is confirmed by the results obtained from BET analysis [29].

\subsection{TEM analysis}

Figure 8 shows the TEM micrographs of Ni-catalysts heat-treated at $700^{\circ} \mathrm{C}$. The $\mathrm{Ni}-\mathrm{Al}_{2} \mathrm{O}_{3}$ catalyst shows uniform distribution of metal particles $(\mathrm{NiO})$ with an average size between 15 and $20 \mathrm{~nm}$. The presence of $\mathrm{NiO}$ crystals is confirmed by XRD analysis for this catalyst in figure 4a. This uniform dispersion is also confirmed by BET analysis because the Ni- $\mathrm{Al}_{2} \mathrm{O}_{3}$ catalyst presents a high surface area.

In the TEM micrograph of the $\mathrm{Ni}-\mathrm{Al}-0.25 \mathrm{Zr}$ catalyst which is represented in figure $8 \mathrm{~b}$, we can see that the addition of $\mathrm{ZrO}_{2}$ to the alumina makes it more difficult to observe the distribution of $\mathrm{NiO}$. It is more difficult because the zirconia can mask the $\mathrm{NiO}$ crystals, since $\mathrm{Zr}$ has a higher electron density than nickel. This result is also observed in the catalyst of $\mathrm{Ni}$ as shown in figure $8 \mathrm{c}$, with $\mathrm{NiO}$ crystals in the range of $20-30 \mathrm{~nm}$. Finally, in the TEM micrograph of Ni-0.25Al-Zr catalyst, crystalline zirconia can be distinguished (figure 8d), which correspond $\mathrm{t}-\mathrm{ZrO}_{2}$ according to the results of XRD (figure $4 \mathrm{~d}$ ).

\subsection{Catalytic evaluation}

The SRE was performed at $500^{\circ} \mathrm{C}$ with an S/E ratio of 3:1. The basic reaction scheme is as follows:

$$
\mathrm{C}_{2} \mathrm{H}_{5} \mathrm{OH}+3 \mathrm{H}_{2} \mathrm{O} \rightarrow 2 \mathrm{CO}_{2}+6 \mathrm{H}_{2} \text {. }
$$

Figure 9 shows ethanol conversion as a function of time over different $\mathrm{Ni}-\mathrm{Al}-\mathrm{Zr}$ catalysts.

The ethanol conversion reached by the $\mathrm{Ni}-\mathrm{Al}-0.25 \mathrm{Zr}$ catalyst is $91 \%$, showing selectivity to hydrogen, carbon dioxide, carbon monoxide and methane of 55.7, 25, 14.1 and $2.8 \%$, respectively, traces of ethylene and acetaldehyde also were detected $(2.3 \%)$ as shown in figure $10 \mathrm{~b}$. Similar results are obtained with the $\mathrm{Ni}-\mathrm{Al}-\mathrm{Zr}$ catalyst as seen in the figure 10c. On the other hand, the ethanol conversion reached by the $\mathrm{Ni}-\mathrm{Al}_{2} \mathrm{O}_{3}$ catalyst is $88 \%$ after $3 \mathrm{~h}$ of reaction with a selectivity of $\sim 52.8,24.2,17.1,3$ and $2.9 \%$ for $\mathrm{H}_{2}$, $\mathrm{CO}_{2}, \mathrm{CO}, \mathrm{CH}_{4}$, traces of $\mathrm{CH}_{3} \mathrm{CHO}$ and $\mathrm{C}_{2} \mathrm{H}_{4}$, respectively (figure 10a).

The presence of a higher concentration of $\mathrm{CO}_{2}$ in the reaction products indicates a methane decomposition reaction of ethanol (equation (2)) and subsequent reforming of methane with steam to form $\mathrm{CO}_{2}$ (equation (3)) [30-32]: 


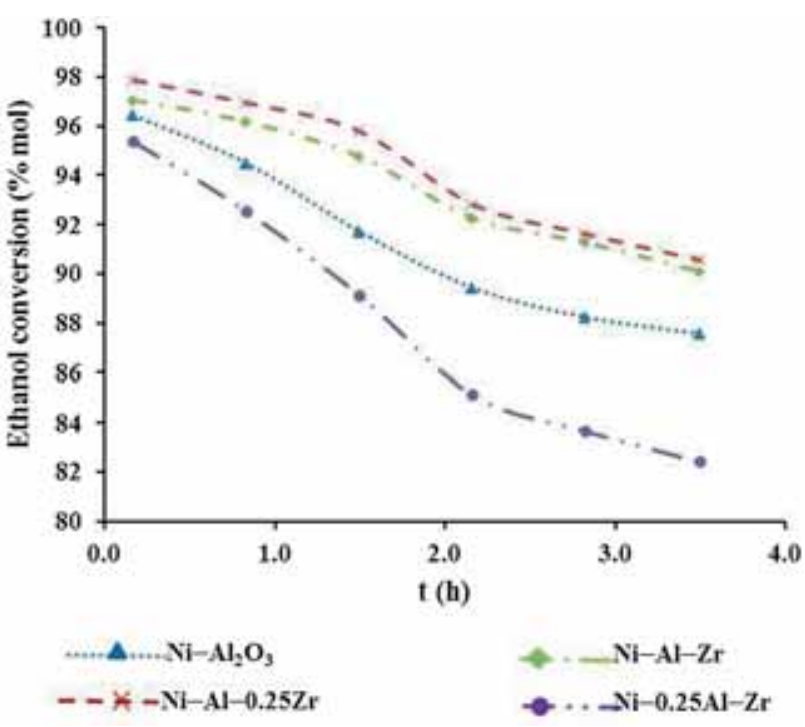

Figure 9. Conversion of ethanol as a function of time on steam reforming reaction for $\mathrm{Ni}-\mathrm{Al}-\mathrm{Zr}$ catalysts.

$$
\begin{aligned}
& \mathrm{C}_{2} \mathrm{H}_{5} \mathrm{OH} \rightarrow \mathrm{CH}_{4}+\mathrm{CO}+\mathrm{H}_{2}, \\
& \mathrm{CH}_{4}+2 \mathrm{H}_{2} \mathrm{O} \rightarrow 4 \mathrm{H}_{2}+\mathrm{CO}_{2} .
\end{aligned}
$$

The gas shift water reaction (WGS) can also occur to form hydrogen and carbondioxide (equation (4)):

$$
\mathrm{CO}+\mathrm{H}_{2} \mathrm{O} \leftrightarrow \mathrm{CO}_{2}+\mathrm{H}_{2} .
$$

The presence of traces of ethylene and acetaldehyde in the reaction products indicate that an ethanol dehydration to ethylene (equation (5)) and ethanol dehydrogenation to acetaldehyde (equation (6)) can also occur:

$$
\begin{aligned}
& \mathrm{C}_{2} \mathrm{H}_{5} \mathrm{OH} \rightarrow \mathrm{CH}_{3} \mathrm{CHO}+\mathrm{H}_{2}, \\
& \mathrm{C}_{2} \mathrm{H}_{5} \mathrm{OH} \rightarrow \mathrm{C}_{2} \mathrm{H}_{4}+\mathrm{H}_{2} \mathrm{O} .
\end{aligned}
$$

Furthermore, acetaldehyde and ethylene in the reforming reaction produce more hydrogen and carbon monoxide equations (7 and 8):

$$
\begin{aligned}
& \mathrm{CH}_{3} \mathrm{CHO}+\mathrm{H}_{2} \mathrm{O} \rightarrow 3 \mathrm{H}_{2}+2 \mathrm{CO}, \\
& \mathrm{C}_{2} \mathrm{H}_{4}+2 \mathrm{H}_{2} \mathrm{O} \rightarrow 2 \mathrm{CO}+4 \mathrm{H}_{2} .
\end{aligned}
$$

The minimum ethanol conversion and selectivity to the products of reaction occurs in $\mathrm{Ni}-0.25 \mathrm{Al}-\mathrm{Zr}$ catalyst (which is richer in zirconia content), reaching a value of $\sim 82.3 \%$ after $3.5 \mathrm{~h}$ of reaction, attributed to increased formation of coke in this catalyst (figure 10d). This is due to traces of ethylene $(1.8 \%)$ and acetaldehyde $(2.3 \%)$ found in the reaction products, which in turn is the precursor of coke formation (equation (9)) and particle size [32]. According to the results of TEM, this catalyst is richer in zirconia content and has a larger particle size, which is less likely to account for the active sites.

$$
\mathrm{C}_{2} \mathrm{H}_{4} \rightarrow \text { polymerization } \rightarrow \text { coke. }
$$

Carbon deposits can also be formed by the Boudouard reaction (equation (10)) and consecutive dehydrogenation of methane (equation (11)):

$$
\begin{aligned}
& 2 \mathrm{CO} \leftrightarrow \mathrm{CO}_{2}+\mathrm{C}, \\
& \mathrm{CH}_{4} \rightarrow \mathrm{CH}_{3} \rightarrow \mathrm{CH}_{2} \rightarrow \mathrm{CH} \rightarrow \mathrm{C} .
\end{aligned}
$$

The results of the SRE indicate that the incorporation of optimal amounts of zirconia into the $\mathrm{Ni} / \mathrm{Al}_{2} \mathrm{O}_{3}$ catalyst provides a strong metal-support interaction, increasing its stability due to higher nickel dispersion on the alumina surface and neutralizing the acidity of the catalyst [33]. Thus, the $\mathrm{Ni}-\mathrm{Al}-0.25 \mathrm{Zr}$ catalyst shows a higher selectivity towards hydrogen due to faster the ethylene and acetaldehyde reforming reactions. In this way, the deactivation of $\mathrm{Ni}-\mathrm{Al}-0.25 \mathrm{Zr}$ catalyst is less than the $\mathrm{Ni}-\mathrm{Al}_{2} \mathrm{O}_{3}$ catalyst.

On the other hand, the incorporation of higher amounts of $\mathrm{ZrO}_{2}$ in the $\mathrm{Ni} / \mathrm{Al}_{2} \mathrm{O}_{3}$ catalyst decrease the surface area of catalyst, which results in weaker metal-support interactions in the $\mathrm{Ni}-0.25 \mathrm{Al}-\mathrm{Zr}$ catalyst, leading to low dispersion of $\mathrm{Ni}$ particles [34]. This increase in the Ni particle size results in a lower selectivity towards hydrogen due to major production of ethylene and acetaldehyde in the reaction products, which causes a fast deactivation of the $\mathrm{Ni}-0.25 \mathrm{Al}-\mathrm{Zr}$ catalyst by coke formation.

The performance of various $\mathrm{Ni} / \mathrm{Al}_{2} \mathrm{O}_{3}, \mathrm{Ni} / \mathrm{ZrO}_{2}$ and $\mathrm{Ni} / \mathrm{Al}-$ $\mathrm{Zr}$ catalysts in SRE is summarized in table 2. For the same operating conditions, the $\mathrm{Ni}-\mathrm{Al}-0.25 \mathrm{Zr}$ catalyst proposed in this study is more selective to hydrogen than the Ni$\mathrm{Al}_{2} \mathrm{O}_{3}$ and $\mathrm{Ni} / \mathrm{ZrO}_{2}$ catalysts of the references. However, the reforming temperature, nickel loading and the molar ratio of water-ethanol play an important role in the conversion of ethanol and selectivity to hydrogen in the SRE as seen in table 2 .

\subsection{Characterization of used catalysts}

The results of coke nature characterization by DTA analysis are shown in figure 11. The DTA profile of the coke deposited on the used $\mathrm{Ni}-0.25 \mathrm{Al}-\mathrm{Zr}$ catalyst shows three combustion peaks at 380,680 and $850^{\circ} \mathrm{C}$, respectively. The peak at $380^{\circ} \mathrm{C}$ evidences the presence of amorphous coke (monoatomic and polymeric carbon) that is adsorbed on the metal sites and cover them (encapsulating carbon) [41,42], which results in a rapid deactivation and low selectivity to $\mathrm{H}_{2}$ as shown in figures 9 and $10 \mathrm{~d}$, respectively. This type of carbon may be attributed to polymeric carbon originating from ethylene polymerization 

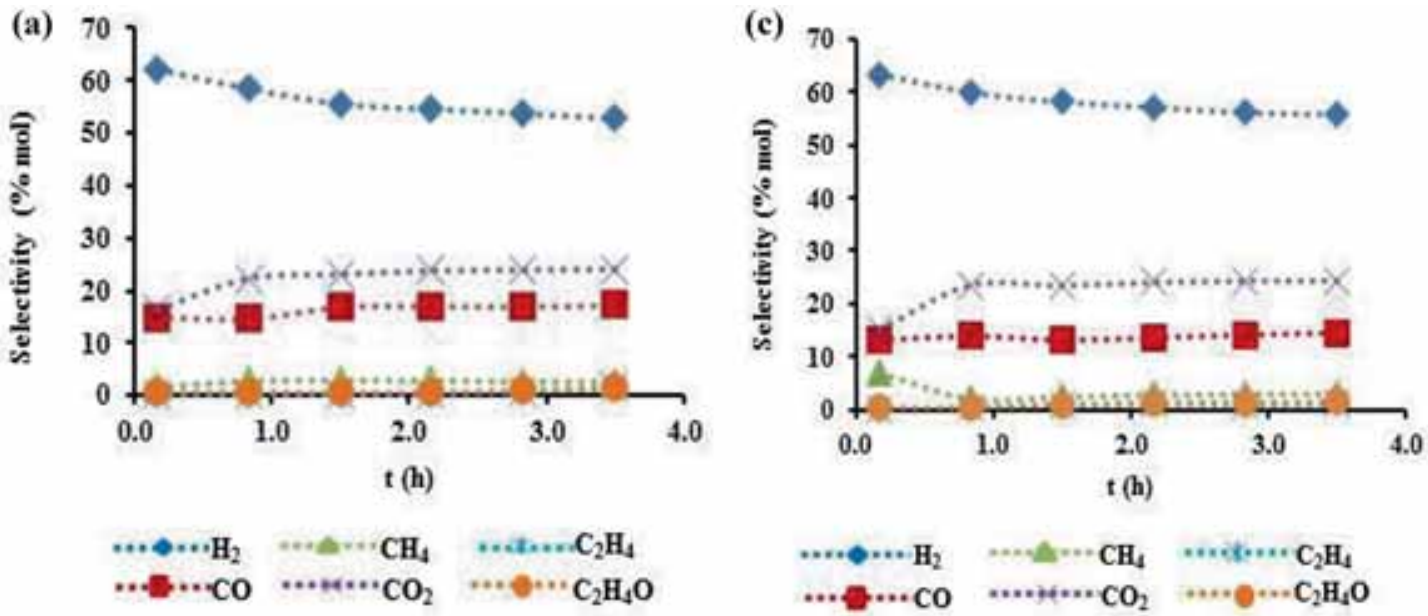

(b)

(d)
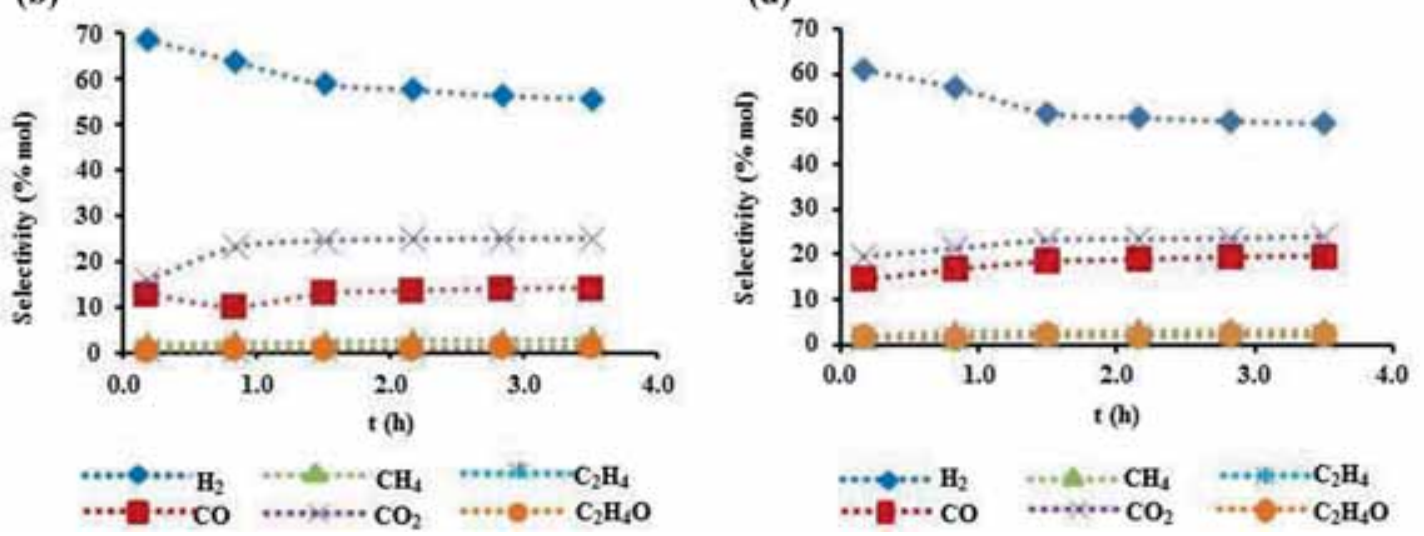

Figure 10. Product distribution for SRE over: (a) $\mathrm{Ni}-\mathrm{Al}_{2} \mathrm{O}_{3}$, (b) $\mathrm{Ni}-\mathrm{Al}-0.25 \mathrm{Zr}$, (c) $\mathrm{Ni}-\mathrm{Al}-\mathrm{Zr}$ and (d) $\mathrm{Ni}-0.25 \mathrm{Al}-\mathrm{Zr}$ catalysts at $500^{\circ} \mathrm{C}$.

Table 2. The performance of $\mathrm{Ni} / \mathrm{Al}_{2} \mathrm{O}_{3}$ and $\mathrm{Ni} / \mathrm{ZrO}_{2}$ catalysts in SRE.

\begin{tabular}{|c|c|c|c|c|c|c|c|}
\hline Catalyst & $\mathrm{Ni}\left(\%_{\mathrm{W}}\right)$ & Temperature $\left({ }^{\circ} \mathrm{C}\right)$ & $\mathrm{H}_{2} \mathrm{O} / \mathrm{EtOH}\left(\mathrm{mol} \mathrm{mol}^{-1}\right)$ & $t(\mathrm{~h})$ & EtOH conversion $(\%)$ & $S_{\mathrm{H}_{2}}(\%)$ & Reference \\
\hline $\mathrm{Ni}-\mathrm{Al}$ & 35 & 500 & 3.3 & 6 & 100 & $\sim 60$ & {$[35]$} \\
\hline $\mathrm{Ni}-\mathrm{Al}$ & 17.4 & 550 & $3: 1$ & 4.1 & 100 & 15 & [36] \\
\hline $\mathrm{Ni}-\mathrm{Al}$ & 16 & 500 & $3: 1$ & 4 & 100 & $\sim 57$ & [34] \\
\hline $\mathrm{Ni}-\mathrm{Al}$ & 15 & 450 & $6: 1$ & NR & 100 & 50 & {$[37]$} \\
\hline $\mathrm{Ni}-\mathrm{Al}$ & 10 & 500 & $3: 1$ & 9 & NR & 30 & [38] \\
\hline $\mathrm{Ni}-\mathrm{Al}$ & 10 & 500 & $4: 1$ & 2 & 100 & 55 & [39] \\
\hline $\mathrm{Ni}-\mathrm{Al}$ & 10 & 400 & $6: 1$ & 3 & 100 & 63.64 & [40] \\
\hline $\mathrm{Ni}-\mathrm{Zr}$ & 10 & 500 & $3: 1$ & 9 & NR & 51 & [38] \\
\hline $\mathrm{Ni}-\mathrm{Al}-0.25 \mathrm{Zr}$ & 10 & 500 & $3: 1$ & 3 & 91 & 55.7 & Present study \\
\hline
\end{tabular}

$\mathrm{NR}=$ not reported

and acetaldehyde decomposition reactions. The combustion peaks at 680 and $850^{\circ} \mathrm{C}$ correspond to the oxidation of a highly graphitic coke [43].

The DTA profile of the coke deposited on the used $\mathrm{Ni}-$ $\mathrm{Al}_{2} \mathrm{O}_{3}$ catalyst shows two combustion peaks at 430 and $650^{\circ} \mathrm{C}$, which correspond to a polymeric and graphitic coke, respectively. Polymeric carbon is first observed at a temperature of $380^{\circ} \mathrm{C}$ in the $\mathrm{Ni}-0.25 \mathrm{Al}-\mathrm{Zr}$ catalyst, while in the $\mathrm{Ni}-\mathrm{Al}_{2} \mathrm{O}_{3}$ catalyst, it is observed up to $430^{\circ} \mathrm{C}$, this is the reason which catalyst activity in the $\mathrm{Ni}-0.25 \mathrm{Al}-\mathrm{Zr}$ catalyst is 


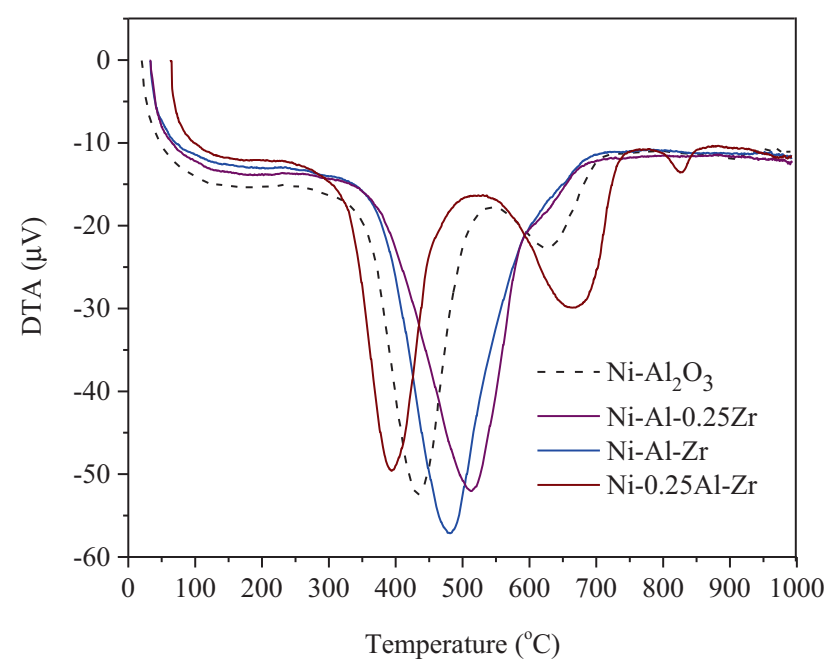

Figure 11. DTA profiles of the used catalysts in SRE at $500^{\circ} \mathrm{C}$.

minor, because the coke encapsulates the Ni particles more rapidly in this catalyst.

The DTA profile of the used $\mathrm{Ni}-\mathrm{Al}-0.25 \mathrm{Zr}$ and $\mathrm{Ni}-\mathrm{Al}-$ $\mathrm{Zr}$ catalysts show a single combustion peak at 490 and $520^{\circ} \mathrm{C}$, respectively, which correspond to filamentous coke (whisker-type carbon) with different graphitization degrees, formed mainly from the Boudouard (equation (10)) and consecutive dehydrogenation of methane reactions (equation (11)) $[31,33,44]$, which do not block metal sites and not necessarily cause a loss of intrinsic catalyst activity. Therefore, this type of carbon allows regeneration of catalysts and its formation occurs at temperatures above $450^{\circ} \mathrm{C}$ [41].

\section{Conclusions}

The characterization results of the $\mathrm{Al}_{2} \mathrm{O}_{3}-\mathrm{ZrO}_{2}$ mixed oxides prepared by sol-gel method showed that the addition of $\mathrm{ZrO}_{2}$ into $\mathrm{Al}_{2} \mathrm{O}_{3}$, reduced the specific surface area, increasing the content of zirconium according to BET analysis. XRD patterns do not clearly identify well-defined crystalline structures corresponding to $\mathrm{ZrO}_{2}$ or $\mathrm{Al}_{2} \mathrm{O}_{3}$ for molar ratios $\left(\mathrm{Al}_{2} \mathrm{O}_{3} / \mathrm{ZrO}_{2}\right)$ of $1: 1,0.25: 1$, and this result in turn suggests that the samples are mostly amorphous solids. However, higher molar ratios of $\mathrm{ZrO}_{2} / \mathrm{Al}_{2} \mathrm{O}_{3}$ show that this fact may be identified as incipient crystallization in the mixed oxide, which is due to the tetragonal phase of zirconia. This phase was clearly characterized in the TGA of the $0.25 \mathrm{Al}-\mathrm{Zr}$ support. The SEM analysis of mixed oxides reveals that the size of the particles increases by increasing the content of zirconium, directly affecting the crystallinity of the nickel catalysts according to the results obtained by XRD and TEM.

$\mathrm{Ni}$ has high activity for $\mathrm{C}-\mathrm{C}, \mathrm{O}-\mathrm{H}$ and $\mathrm{C}-\mathrm{H}$ bonds breaking, facilitating $\mathrm{H}$ atoms to form molecular $\mathrm{H}_{2}$ and converting $\mathrm{CO}$ to $\mathrm{CO}_{2}$. However, the Ni catalyst suffers from coke formation as well as metal sintering, leading to rapid deactivation in SRE. The $\mathrm{Al}_{2} \mathrm{O}_{3}$ is a support with strong acidic nature, which promotes dehydration reaction of ethanol to ethylene causing the formation of amorphous coke and deactivating the Ni particles rapidly. The $\mathrm{ZrO}_{2}$ was introduced to alumina to improve the $\mathrm{Ni}-\mathrm{Al}_{2} \mathrm{O}_{3}$ catalyst stability by suppressing the acidity of carrier and minimized the dehydration of ethanol on the alumina support.

The activity of the studied catalysts of $\mathrm{Ni}$ indicates that conversion of ethanol and selectivity towards $\mathrm{H}_{2}$ in the SRE, progressively decreases with the increment in zirconia content. This is due to the increase of the mean particle size and crystallinity, resulting in further formation of coke by the ethylene route in the ethanol reforming reaction. The DTA results of the used catalysts indicate that optimal incorporation of $\mathrm{ZrO}_{2}$ into the $\mathrm{Ni}-\mathrm{Al}_{2} \mathrm{O}_{3}$ catalyst improves its stability and resistance to the formation of polymeric coke (below $450^{\circ} \mathrm{C}$ ). The deposited coke is filamentous (formed above $450^{\circ} \mathrm{C}$ through Bourduard reaction and consecutive dehydrogenation of methane), which does not encapsulate the nickel particles and has a minor effect on the deactivation of the catalyst by coke, allowing its regeneration. Therefore, the proposed catalyst can also be used in reforming the natural gas or other hydrocarbons.

\section{Acknowledgements}

J Angel-Soto expresses thanks to the University of Guanajuato and to CONACYT, for the financial support granted to this project.

\section{References}

[1] Chen X, Liu Y, Niu G, Yang Z, Blan M and He A 2001 Appl. Catal. A: General 205159

[2] Khalaf H A 2013 SpringerPlus 21

[3] Dabbagh H A and Zamani M 2011 Appl. Catal. A: General 404 141

[4] Davies L E, Bonini N A, Locatelli S and Gonzo E E 2005 Lat. Am. Appl. Res. 3523

[5] Liu X, Lu G and Yan Z 2003 J. Nat. Gas Chem. 12161

[6] Teterycz H, limkiewicz R K and Laniecki M 2003 Appl. Catal. A: General 249313

[7] Ortiz-Landeros J, Contreras García M E and Pfeiffe H 2007 Adv. In Tech. Mat. Mat. Proc. 9119

[8] Hong D Y, Vislovskiy V P, Park Y H and Chang J S 2006 Bull. Korean Chem. Soc. 27789

[9] Chary K V R, Kumar Ch P, Rao P V R and Rao V V 2004 Catal. Commun. 5479

[10] Seo J G, Youn M H, Park S, Chung J S and Song I K 2009 Int. J. Hydrogen Energ. 343755

[11] Li H and Wang J 2004 Chem. Eng. Sci. 594861

[12] Ping H Z, Chun H, Zheng J and Lu G Q 2004 J. Environ. Sci. (China) 16316

[13] Carmo Rangel M, Paternina Berrocal G, Maciel C G and Mansu Assaf J 2011 Adv. Chem. Res. 10341

[14] Wang S and Lu G 1998 Appl. Catalysis-B: Environ. 16269 
[15] Iriondo A, Barrio V L, Cambra J F, Arias P L, Güemez M B, Navarro R M et al 2008 Top. Catal. 4946

[16] Angel J, Aguilera A F, Galindo I R, Martinez M and Viveros T 2012 Mater. Sci. Appl. 3650

[17] Klimova T, Rojas M L, Castillo P, Cuevas R and Ramirez J 1998 Micropor. Mesopor. Mater. 20293

[18] Chen Y W, Yen T M and Li C 1995 J. Non-Cryst. Solids 185 49

[19] Li G, Li W, Zhang M and Tao K 2004 Catal. Today 93-95 595

[20] Sarkar D, Mohapatra D, Ray S, Bhattacharyya S, Adak S and Mitra N 2007 Ceram. Int. 331275

[21] Cai M, Wen J, Chu W, Cheng X and Li Z 2011 J. Nat. Gas Chem. 20318

[22] Ding R G and Yan Z F 2002 Fuel Chem. Division Preprints 47 108

[23] Youn M H, Seo J G, Jung J C, Park S and Song I K 2009 Int. J. Hydrogen Energ. 345390

[24] Liu Q, Wang A, Wang X, Gao P, Wang X and Zhang T 2008 Micropor. Mesopor. Mater. 111323

[25] Tursiloadi S, Imai H and Hirashima H 2004 Indonesian J. Chem. 4149

[26] Kirszensztejn P and Szymkowiak A 2005 J. Therm. Anal. Calorim. 8135

[27] Perez-Pastenes H, Ochoa-Tapia A and Viveros T 2006 J. SolGel Sci. Technol. 3749

[28] Zawadzki M, Hreniak D, Wrzyszcz J, Mista W, Grabowska H, Malta O L et al 2003 Chem. Phys. 291275

[29] Nouri E, Shahmiri M, Rezaie H R and Talayian F 2012 Int. J. Ind. Chem. 31
[30] Benito M, Sanz J L, Isabel R, Padilla R, Arjona R and Daza L 2005 J. Power Sources 15111

[31] Fatsikostas A N and Verykios X E 2004 J. Catal. 225 439

[32] Cavallaro S 2000 Energy Fuels 141195

[33] Sanchez-Sanchez M C, Navarro R M and Fierro J L 2007 Int. J. Hydrogen Energ. 321462

[34] Pompeo F, Nichio N N, Souza M M V M, Cesar D V, Ferretti O A and Schmal M 2007 Appl. Catal. A: General 316 175

[35] Comas J, Marino F, Laborde M and Amadeo N 2004 Chem. Eng. J. 9861

[36] Fajardo H V, Longo E, Mezalira D Z, Nuernberg G B, Almerindo G I et al 2010 Environ. Chem. Lett. 879

[37] Liberatori J W C, Ribeiro R U, Zanchet D, Noronha F B and Bueno J M C 2007 Appl. Catal. A: General 327197

[38] Saeki T, Ohkita H, Kakuta N and Mizushima T 2015 J. Jpn. Petrol. Inst. 58341

[39] Denis A, Grzegorczyk W, Gac W and Machocki 2008 Catal. Today $\mathbf{1 3 7} 453$

[40] Bshish A,Yaakob Z, Ebshish A and Alhasan F H 2013 ASME J. Energy Resour. Technol. 136012601

[41] Bartholomew C H 2001 Appl. Catal. A: General 21217

[42] Montero C, Valle B, Bilbao J and Gayubo A 2014 Chem. Eng. Trans. 37481

[43] Vicente J, Montero C, Ereña J, Azkoiti M J, Bilbao J and Gayubo A G 2014 Int. J. Hydrogen Energ. 3912586

[44] Cheng H, Feng S, Tao W, Lu X, Yao W, Li G et al 2014 Int. J. Hydrogen Energ. 3912604 